\title{
IAMJ
}

INTERNATIONAL

AYURVEDIC

MEDICAL JOURNAL

[ब] (2)

Case Report

ISSN: 2320-5091

Impact Factor: 6.719

\section{TREATING KARNA SRAVA THROUGH AYURVEDA - A CASE STUDY}

\section{Prakruthi G}

Assistant Professor, Department of Shalakya Tantra

Sri Paripoorna Sanathana Ayurveda Medical College Hospital and Research Centre, Arjunabettahalli, Nelamangala, Bangalore - 562123, Karnataka, India

Corresponding Author: prakruthikalpana@gmail.com

https://doi.org/10.46607/iamj14p5022020

(Published online: January 2021)

Open Access

(C) International Ayurvedic Medical Journal, India 2021

Article Received: 29/12/2020 - Peer Reviewed: 06/01/2021 - Accepted for Publication: 15/01/2021

Check for updates

\section{ABSTRACT}

Karna (ear), the organ of hearing is considered as one among the Navadwaras which is predominant in Akasha Mahabhuta. Karna Srava is one among the 28 Karna Rogas explained by Acharya Sushruta. The present article emphasises the importance of Sthanika Chikitsopakramas used to treat the disease Karna Srava successfully. A 24year male patient approached Shalakya tantra OPD of SPSAMCH and RC, Arjunabettahalli, Nelamangala with the complaints of right ear pain for 3 days associated with itching. On examination, pus and fungus mass were found in the right ear and tympanic membrane was not visible. It was treated accordingly using appropriate Sthanika Chikitsopakramas like Karna Prakshalana and Karna Dhupana and Shamanoushadhis which gave complete relief to the patient. Based on the Lakshanas in the present case, Karna Srava is corelated to otomycosis which is having the similar symptoms. Otomycosis is a fungal infection of the ear canal with the symptoms of pain, itching, discharge and ear block. Any ailment connected with the ear should be treated as early as possible due to the importance of organ of hearing and also due to its delicacy and inaccessibility.

Keywords: Karna Srava, Otomycosis, Karna Prakshalana, Karna Dhupana.

\section{INTRODUCTION}

Shalakya tantra ${ }^{l}$ is the branch dealing with Urdhwajatrugata Rogas and its Chikitsa in detail. It involves all the diseases and its treatment affecting Netra (eye), Karna (ear), Nasa (nose), Asya (mouth) and Kanta (throat) and all Chikitsopakramas to treat the diseases affecting it, including Shastra Chikitsa. 
Karna, one among the panchendriya, ${ }^{2}$ is responsible for shabdagrahana ${ }^{3}$ and is considered as a bahyasrotas. ${ }^{4}$ Acharya Sushruta has explained 28 Karna Rogas ${ }^{5}$ in detail which includes the signs and symptoms and treatment. He has included Karna Srava as one among the Karna Roga. Acharya Vagbhata has explained 25 Karna Rogas ${ }^{6}$ but he did not explain Karna Srava under Karna Roga.

About the disease Karna Srava - Due to Agantuja or Doshaja Nidana there will be formation of pus due to the vitiation of Kapha Dosha. Due to Pittoshmata, the pus will be liquified and by Chalaguna of Vata Dosha it will flow out. Karna Srava is one of the clinical features of the many disease such as otitis externa, otomycosis, chronic suppurative otitis media, furunculosis in external ear, diffuse otitis externa etc., The treatment principle of Karna Srava is same like Krimikarna and Putikarna which mainly includes Karna Prakshalana, Karna Dhupana, Karna Pramarjana, Karna Pichu, Shirovirechana, Snehana, Swedana, Gandusha, Kavala, Dushtavrana Chikitsa based on the symptomatology. ${ }^{7}$

About the disease Otomycosis - Otomycosis is a fungal infection of the ear canal that often occurs due to Aspergillus Niger, A. fumigatus or Candida albicans. The clinical features of otomycosis includes intense itching, discomfort or pain in the ear, watery discharge with a musty odour and ear blockage. The fungal mass may appear white, brown or black. On examination with an otoscope, A. Niger appears as black headed filamentous growth, A. fumigatus, pale blue or green and Candida as white or creamy deposit. Meatal skin appears sodden, red and oedematous. Treatment consists of thorough ear toilet to remove all discharge and epithelial debris which are conducive to the growth of fungus. It can be done by syringing, suction or mopping. Specific antifungal agents can be applied. Antifungal treatment should be continued for a week even after apparent cure to avoid recurrences. Ear must be kept dry. ${ }^{8}$ Case Report: A 24-years male patient approached Shalakya tantra OPD of SPSAMCH and RC, Arjunabettahalli, Nelamangala (IPD No. - 460) presented with pain and itching sensation in right ear for 3 days. When he woke up from the sleep, he noticed slight pain in the right ear and as the day advanced it started aggravating. He neglected as that was not disturbing his routine activities. Later since morning the pain got aggravated and he approached to us and he had the same episode of ear discharge 2 months before. On examination external auditory canal of the right ear was filled with purulent discharge and after Pramarjana fungus moulds were found which was adhered to the tympanic membrane. The left ear canal was clear with visible normal tympanic membrane.

\section{Treatment:}

- The purulent discharge was removed by wiping (Karna Pramarjana) followed aural syringing (Karna Prakshalana) using Triphala Kashaya.

- Karna Prakshalana was continued for 4 more days with Gomutrarka Pichu to control the discharge and to cleanse the entire canal.

- Karna Dhupana with Haridradi Varti is done for next 3 days.

- Internally,

Triphala Guggulu was given 2 BD for 5 days.

Tab. Nirocil was given 1BD for 10 days.

Tab. Septec was given 1BD for 5 days.

Specific advice for patient - Patient was advised not to take head bath, not to consume refrigerated food items, not to be exposed for cold wind. Ear canal should be kept dry.

\section{Karna Prakshalana:}

- The patient was made to sit on a comfortable chair.

- Lukewarm Triphala Kashaya is taken in a $10 \mathrm{ml}$ syringe.

- A kidney tray is placed over the shoulder. Patient's head is slightly tilted over the tray to collect the return fluid.

- Pinna is pulled upwards and backwards and a stream of Kashaya from the ear syringe is directed along the posterosuperior wall of the meatus.

- At the end of the procedure, ear canal and tympanic membrane must be inspected and dried with a pledget of cotton.

\section{Karna Pichu:}

- Karna Pramarjana was done to remove the moisture from the ear canal.

- Gomutrarka was taken in a cotton wick and 
placed over the affected site for 3 hours.

- After 3 hours, wick should be removed, and fresh cotton plugs was kept.

Haridradi Dhupa: Fumes coming out of burnt Haridradi Dhuma Varti were directed to both the ears and cotton plug was kept after Dhupana.

\section{OBSERVATION AND RESULTS:}

Mucopurulent discharge in the ear was due to the fungus infection. Ear pain was reduced after 3 days of Karna Prakshalana. Ear itching reduced by $5^{\text {th }}$ day. Discharge was reduced markedly by 6th day, of Karna Prakshalana, Pramarjana and Pichu Dharana. For next 3 days, Karna Dhupana was done after which there was a complete reduction in all the symptoms. Follow up was done on $15^{\text {th }}$ day and $30^{\text {th }}$ day and there is complete absence of all the symptoms.

\section{DISCUSSION}

General management of ear disease includes oral intake of ghrita, rasayanas, avoidance of physical exercise, bathing without wetting the head, celibacy and vocal rest. In the present case, firstly Karna Prakshalana was done using Triphala Kashaya to clean the surface area which has got infected due to the fungus infection. After the part has cleaned with Gomutrarka Pramarjana followed Karna Pichu using Gomutraka. After the wound started healing, Haridradi Dhupa was given to normalise the ear canal by controlling Vata which is the prime cause.

Mode of action of karna prakshalana: Triphala contains Amalaki, Vibhitaki, Hartitaki in equal quantity. These drugs have anti-inflammatory and anti- microbial activities which helps in easy clearing of infection and reduction in pain. ${ }^{9}$

Mode of action of Pichu: It is a unique drug delivery system. system. Gomutraka used in the present case. Fungicidal effect against Aspergillus fumigatus, Aspergillus flavus, Aspergillus Niger, Aspergillus, Malassezia, C. tropicalis and C. glabrata has been observed in various studies. ${ }^{10}$

Mode of action of haridradi Dhuma: Haridadi Dhuma Varti contains Triphala, Trikatu, Haridra and Triphala Ghrita. Mainly it contains Haridra. Many studies have reported Anti -inflammatory, anti -fungal, anti-microbial activities of haridra. ${ }^{11}$ The proven antiinflammatory and antifungal activity of Haridra and other drugs in the Varti has given added effect and also in the form of Dhupa where it can combat the pain caused due to impaired Vata Dosha. The internal medicines given are Triphala Guggulu, Tab.Septec and Tab.Nirocil. All are said to be potent anti-allergic and anti-infective which have further helped in steady wound healing.

\section{CONCLUSION}

In the present case, carefully the fungal mass is removed with the help of Sthanika Chikitsopakramas and the canal was cleared. Unskilled attempts at removal of adhered fungal mass may lacerate the meatal lining, damage the tympanic membrane or the ear ossicles. Precautionary measures have to be taken while attempting such cases. The main aim in treating this condition is to control the vitiated Kapha and Vata Dosha. Selection of appropriate Sthanika Chikitsopakramas along with internal medicines has helped to treat a case of Karna Srava successfully through Ayurvedic management.

\section{REFERENCES}

1. Sushrutha Samhita, with Sri Dalhanacharya Teeka, edited by Narayan Ram Acharya Kavyathirtha, Chaukhambha Orientalia, Varanasi, reprint edition-2009, Sutra sthana, 1st chapter, Verse-7(2), pp-824, pg-2.

2. Agnivesha, Charaka Samhita, Revised by Charaka and Dridhabala, Ayurveda Dipika Commentary of Chakrapani Datta, Edited by Vaidya Jadavji Trikamji Acharya, Chowkhamba Krishnadas Academy, Varanasi, Reprint-2010, Sutra Sthana, 8th Chapter, Verse-3, pp - 738, pg - 55 .

3. Agnivesha, Charaka Samhita, Revised by Charaka and Drdhabala, Ayurveda Dipika Commentary of Chakrapani Datta, Edited by Vaidya Jadavji Trikamji Acharya, Chowkhamba Krishnadas Academy, Varanasi, Reprint-2010, Sutra Sthana, 24th Chapter, Verse11, pp - 738, pg - 56.

4. Agnivesha, Charaka Samhita, Revised by Charaka and Drdhabala, Ayurveda Dipika Commentary of Chakrapani Datta, Edited by Vaidya Jadavji Trikamji Acharya, Chowkhamba Krishnadas Academy, Varanasi, Reprint-2010, Shareera Sthana, 7th Chapter, 
Verse-13, pp - 738, pg - 338.

5. Sushrutha Samhita, with Sri Dalhanacharya Teeka, edited by Narayan Ram Acharya Kavyathirtha, Chaukhambha Orientalia, Varanasi, reprint edition-2009, Uttara tantra, 20th chapter, Verse-7(2), pp-824, pg-539.

6. Ashtanga Hridaya with commentaries Sarvangasundari of Arunadatta and Ayurvedarasayana of Hemadri, Annotated by Dr Anna Moreswar Kunte and Krishna Ramachandra Shastri Narre, edited by Pt. HariSadasiva Sastri, Chaukhamba Surabharati Prakasan, Varanasi, Edition 2008, Uttaratantra, 17th chapter, verse-42, pp956, pg-735.

7. A textbook of Shalakya Tantra, Vol.2, Karna, Nasa, Shiro and Mukha Rogas, Dr. Adikanda Biswal, Dr. Rasmita Routaray - Chaukhambha publications, New delhi - Reprint edition - 2020, Chapter - 2 .

8. Diseases of Ear, Nose and throat, P L Dhingra, B.I. Churchill Livinstone Pvt Ltd, Reprinted edition, pp 415, pg - 51-52.

9. Study of antimicrobial activity of Triphala and its individual components, Mehul M Sheta, IJHM 2016; 4(5):41-43.

10. Chemotherapeutic potential of cow urine: A review Gurpreet Kaur Randhawa1, Rajiv Sharma2, Journal of Intercultural Ethnopharmacology DOI: $10.5455 /$ jice. 2015022210032

11. Journal of Pharmacognosy and Phytochemistry, Pharmacological activities of wild turmeric (Curcuma aromatica Salisb): a review, Sikha A, Harini A, Hegde Prakash L, P-ISSN: 2349-8234 JPP 2015; 3(5): 01-04

\section{Source of Support: Nil \\ Conflict of Interest: None Declared}

How to cite this URL: Prakruthi G: Treating Karna Srava Through Ayuveda - A Case Study. International Ayurvedic Medical Journal \{online\} 2021 \{cited January, 2021\} Available from: http://www.iamj.in/posts/images/upload/2746_2749.pdf 